\title{
Impact of the new electric arc furnace on the level of flicker in surrounding transmission and distribution power system
}

\author{
Ana Tomasović Teklić ${ }^{1}$, Ivan Periša ${ }^{2}$ and Davor $\breve{S ̌ k r l e c}^{3}$ \\ ${ }^{1}$ Končar Electrical Engineering Institute \\ Fallerovo setaliste 22, 10000 Zagreb (Croatia) \\ Phone:+385 1 3655243, fax: +385 1 3667309, e-mail: ana.tomasovic@koncar-institut.hr \\ ${ }^{2}$ HEP - Distribution System Operator \\ Ulica grada Vukovara 37, 10000 Zagreb (Croatia) \\ Phone:+385 1 6321953, fax: +385 1 6171282, e-mail: ivan.perisa@hep.hr \\ ${ }^{3}$ Faculty of Electrical Engineering and Computing \\ Unska 3, 10000 Zagreb (Croatia) \\ Phone:+385 1 6129921, fax: +385 1 6129890, e-mail: davor.skrlec@fer.hr
}

\begin{abstract}
Point of connection of Ironworks is $110 \mathrm{kV}$ bus in 110/35(33) kV "Željezara 1" substation in Sisak in Croatian transmission power system. Installation of new electric arc furnace, requires increased agreed power for Ironworks from TSO. New electric arc furnace is connected on low voltage side of T3 transformer with ratio $110 / 33 \mathrm{kV}$. As a part of the test operation of the new electric arc furnace in Ironworks in Sisak, detailed measurements of Voltage Quality, in different operating modes of the arc furnace were performed. The purpose of the measurements was to determine Voltage Quality on point of connection of Ironworks during the test operation of new arc furnace and to determine negative influence of Ironworks on Voltage Quality according to the Grid Code of Croatian Power System. Measurements were performed simultaneously at point of connection of Ironworks and surrounding transmission and distribution power network. Measurement results show that in all measuring points flicker short-term and long-term flicker severity exceeds prescribed limits according to the Grid Code of Croatian Power System. From the measurement flicker transfer coefficients between different voltage levels were calculated and conclusion about flicker attenuation was given.
\end{abstract}

\section{Key words}

Electric arc furnace, flicker, distribution power network, transmission power network, Grid Code of Croatian Power System.

\section{Introduction}

Electric arc furnace is very unpredictable load that causes disturbances in the power system such as rapid voltage fluctuations called flicker in frequency range from 0,5 to $25 \mathrm{~Hz}$, voltage unbalance, harmonics etc.
As a part of the test operation of the new electric arc furnace rated power $63 \mathrm{MVA}$, detailed measurements of Power Quality, in different operating modes of the arc furnace were performed. The purpose of the measurements was to determine Power Quality on point of connection of Ironworks (110 kV bus in 110/35(33) $\mathrm{kV}$ "Željezara 1" substation in Sisak) during the test operation of new arc furnace, after the first phase of installation and to determine influence of Ironworks on Voltage Quality (with emphasis on flicker) according to the Grid Code of Croatian Power System (official gazette 36/06).

Measurements were performed at $110 \mathrm{kV}$ side of transformer T3 (on the low voltage side of this transformer $110 / 33 \mathrm{kV}$ electric arc furnace is connected) at $110 / 35(33) \mathrm{kV}$ "Željezara 1" substation in Sisak. Measurements were also simultaneously performed in the surrounding transmission and distribution power network, in order to obtain the impact of the new electrical arc furnace on the Power Quality in electrically close points of the power system. Particular emphasis is placed on identifying ways of flicker propagation through the surrounding power network, away from the source (new electric arc furnace) as a function of the length of the network itself, and through the transformations on the lower voltage levels. Results of measurements were analyzed according to International Standards and Technical Reports and the Grid Code of Croatian Power System (official gazette 36/06), depending on the voltage level and significance of the measurement point. 


\section{Measurement}

Measurements were performed in six measurement points - three measurement points in transmission power grid and three measurement points in distribution power grid:

- MP1 - $110 \mathrm{kV}$ bus in 110/35(33) kV substation "Željezara 1" - T3 transformer

- MP2 - $110 \mathrm{kV}$ bus in 220/110 kV substation "TE Sisak"

- $\quad$ MP3 - $110 \mathrm{kV}$ bus in $110 / 35 \mathrm{kV}$ substation "Pračno"

- MP4 - $10 \mathrm{kV}$ bus in 110/10 kV substation "Petrinja"

- MP5 - 0,4 kV bus in 10/0,4 kV substation "Hrastovica" (first substation of $10 \mathrm{kV}$ feeder "Jabukovac" from 110/10 kV "Petrinja" substation)

- $\quad$ MP6 - 0,4 kV bus in 10/0,4 kV substation "Banski Grabovac 1" (last substation of $10 \mathrm{kV}$ feeder "Jabukovac" from 110/10 kV "Petrinja" substation)

Measurements were performed with modern Power Quality analyzers Power Measurements - ION 7650 and Lem - Memobox 808A in all measurement points. Voltage Quality parameters were measures in all measurement points, with addition of load measurement in MP1 (110 bus in 110/35(33) kV "Željezara 1" substation - T3 transformer on which new electric arc furnace is connected) to determine the impact of new electric arc furnace on Voltage Quality of the surrounding power system. Measurements were performed simultaneously in one week period from 27.07.2011. (Wednesday) do 03.08.2011. (Wednesday).

Measurement results were analyzed (depending on the measurement point) according to following International Standards and Technical Reports:

\section{- IEC 61000-3-6:2008}

Electromagnetic compatibility (EMC) - Part 3-6: Limits Assessment of emission limits for the connection of distorting installations to $\mathrm{MV}, \mathrm{HV}$ and $\mathrm{EHV}$ power systems"

\section{- $\quad$ IEC 61000-3-7:2008}

Electromagnetic compatibility (EMC) - Part 3-7: Limits Assessment of emission limits for the connection of fluctuating installations to $\mathrm{MV}, \mathrm{HV}$ and $\mathrm{EHV}$ power systems"

\section{- IEC 61000-3-13:2008}

Electromagnetic compatibility (EMC) - Part 3-13: Limits - Assessment of emission limits for the connection of unbalanced installations to $\mathrm{MV}, \mathrm{HV}$ and $\mathrm{EHV}$ power systems"

\section{- $\quad$ EN 50160:2008}

"Voltage characteristics of electricity supplied by public distribution networks"

Point of connection of network customer Ironworks "Sisak" is located at $110 \mathrm{kV}$ bus in $110 / 35(33) \mathrm{kV}$ "Željezara 1" substation (MP1), measurement of Voltage Quality and negative influence on Voltage Quality were analyzed according to Grid Code of Croatian Power System.
Measurement points on the network customer location (110/35(33) kV "Željezara 1" substation) and in surrounding power system are shown on Figure 1.

The connection of 110/35(33) kV "Željezara 1" substation and surrounding transmission power grid (220/110 kV "TE Sisak", 110/35 kV "Pračno" and 110/10 $\mathrm{kV}$ "Petrinja" substation)is shown on Figure 2.

110/35(33) kV "Željezara 1" substation currently contains two transformers, T1 and T3 (both rated power 63 MVA). Transformers are separated on the low voltage side. Transformer T3 feeds the new electric arc furnace and devices for compensation and filtering of $3^{\text {rd }}$ and $4^{\text {th }}$ harmonic, while transformer T1 feeds remaining loads of Ironworks (old arc furnace rated power of 16 MVA, "Felis" with rated power of 4 MVA and "VBC" with rated power of $12 \mathrm{MVA}$ ).

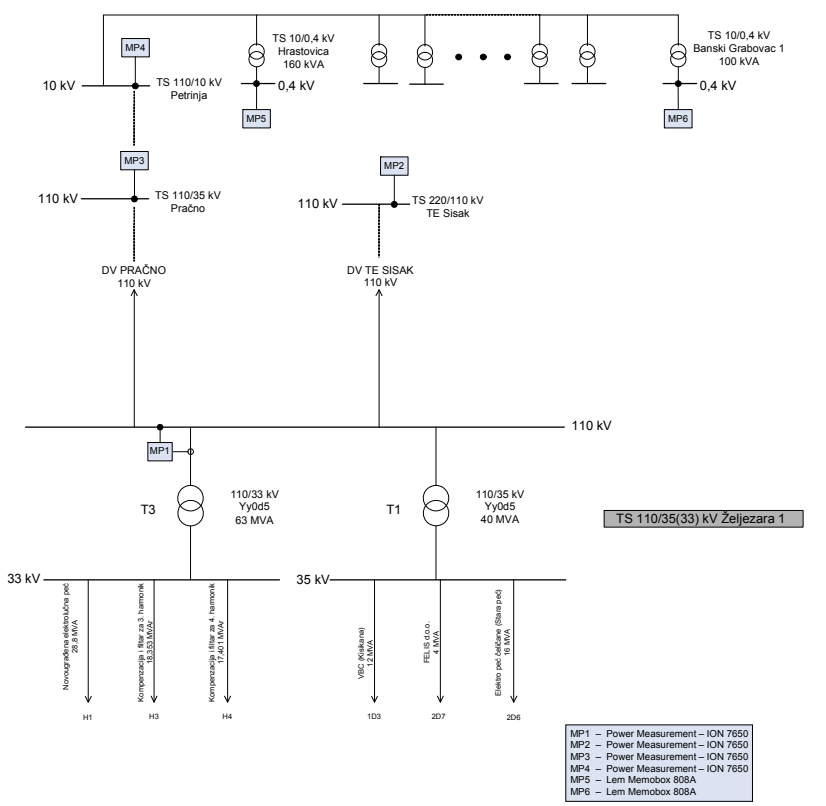

Fig. 1. Measurement points on the network customer location (110/35(33) kV "Željezara 1" substation) and in surrounding power system

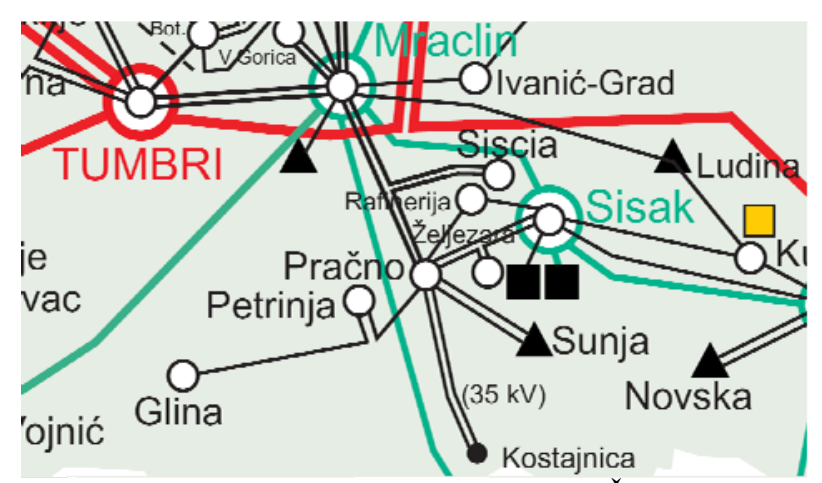

Fig. 2. connection of 110/35(33) kV "Željezara 1" substation and surrounding transmission power grid

\section{IEC 61000-3-7:2008 [2]}

Technical Report IEC 61000-3-7:2008 "Electromagnetic compatibility (EMC), Part 3-7: Limits - Assessment of emission limits for the connection of fluctuating installations to $\mathrm{MV}, \mathrm{HV}$ and $\mathrm{EHV}$ power systems" 
provides guidance to system operator on principles which can be used as the basis for determining the requirements for the connection of fluctuating installations to MV, HV and EHV public power systems (LV installations are covered in other IEC documents). For the purposes of this report, a fluctuating installation means an installation (which may be a load or a generator) that produces voltage flicker and/or rapid voltage changes. The primary objective is to provide guidance to system operators or owners on engineering practice which will facilitate the provision of adequate service quality for all connected customers.

Compatibility levels represent reference values for coordinating the emission and immunity of equipment which is part of or supplied by, a supply system in order to ensure the EMC in the whole system (including system and connected equipment). Compatibility levels are generally based on $95 \%$ probability levels of entire system, using statistical distributions which represent both time and space variations of disturbances. There is allowance for the fact that system operator or owner cannot control all points of a system at all times.

Planning levels are levels that can be used for the purpose of determining emission limits, taking into consideration all fluctuating installations. Planning levels are specified by the system operator or owner for all system voltage levels and can be considered as internal quality objectives of the system operator or owner. Planning levels should allow coordination of voltage fluctuations between different voltage levels.

Planning levels are generally lower (or equal) than the compatibility levels. (Compare Tables I and II)

Compatibility levels for flicker in low voltage systems reproduced from IEC 61000-2-2 is shown in Table I.

Table I. - compatibility levels for flicker in low voltage systems reproduced from IEC 61000-2-2 [2]

\begin{tabular}{|c|c|}
\hline & Compatibility levels \\
\hline $\mathrm{P}_{\mathrm{st}}$ & 1,0 \\
\hline $\mathrm{P}_{\mathrm{lt}}$ & 0,8 \\
\hline
\end{tabular}

Indicative values of planning levels for flicker in MV, $\mathrm{HV}$ and EHV power systems are shown in Table II.

Table II. - Indicative values of planning levels for flicker in $\mathrm{MV}, \mathrm{HV}$ and EHV power systems [2]

\begin{tabular}{|c|c|c|}
\hline \multirow{2}{*}{} & \multicolumn{2}{|c|}{ Planning levels } \\
\cline { 2 - 3 } & $\mathrm{SN}$ & VN I VVN \\
\hline $\mathrm{P}_{\mathrm{st}}$ & 0,9 & 0,8 \\
\hline $\mathrm{P}_{\mathrm{lt}}$ & 0,7 & 0,6 \\
\hline
\end{tabular}

\section{Measurement analyses}

Measurements of Voltage Quality (with emphasis on flicker) were simultaneously performed at point of connection of Ironworks "Sisak" and in the surrounding transmission and distribution power network (six measuring points), in order to obtain the impact of the new electrical arc furnace on the Power Quality in electrically close points of the power system.
Measurement results show that all of the measured values of Voltage Quality parameters except for short-term and long-term flicker severity are below the upper limit of planning levels recommended by Technical Reports IEC 61000-3-6:2008 for harmonic voltage distortion, IEC 61000-3-7:2008 for flicker severity and IEC 61000-313:2008 for voltage unbalance (all values refer to the maximum value in $95 \%$ of the time). Also, the measured values of frequency and voltage are within permissible limits, while flicker severity exceeds permissible limits according to Grid Code of Croatian Power System.

Measurement results for flicker severity for all 6 measuring points are given in table III.

Table III. - Measurement results for flicker severity at point of connection of Ironworks and surrounding transmission and distribution power grid

\begin{tabular}{|c|c|c|c|}
\hline \multirow[t]{2}{*}{ MP } & \multirow[t]{2}{*}{$\begin{array}{c}\text { PERMISSIBLE } \\
\text { LIMITS } \\
\text { ACCORDING TO: } \\
\text { GRID CODE OF } \\
\text { CROATIAN POWER } \\
\text { SYSTEM } \\
\text { In 100\% of the } \\
\text { time, } \\
\text { RECCOMENDED } \\
\text { LIMITS } \\
\text { ACCORDING TO: } \\
\text { IEC 61000-3- } \\
7: 2008 \\
\text { in 95\% of the time, } \\
\text { and } \\
\text { EN 50160:2008 } \\
\text { in 95\% of the time }\end{array}$} & \multicolumn{2}{|c|}{$\begin{array}{l}\text { MEASURED VALUE } \\
\text { Short-term flicker severity } \mathrm{P}_{\mathrm{st}} \\
\text { Long-term flicker severity } \mathrm{P}_{\mathrm{lt}}\end{array}$} \\
\hline & & $\mathbf{P}_{\mathrm{st}}$ & $\mathbf{P}_{\mathrm{It}}$ \\
\hline MP1 & $\begin{array}{l}\mathrm{P}_{\mathrm{st}} \leq 0,8 \\
\mathrm{P}_{\mathrm{lt}} \leq 0,6\end{array}$ & $\begin{array}{l}\mathrm{L} 1-1,76^{*} / 3,88^{* *} \\
\mathrm{~L} 2-1,78^{*} / 3,81^{* *} \\
\mathrm{~L} 3-1,83 * / 4,74 * *\end{array}$ & $\begin{array}{l}\mathrm{L} 1-1,71^{*} / 2,13^{* *} \\
\mathrm{~L} 2-1,66^{*} / 2,08^{* *} \\
\mathrm{~L} 3-1,71^{*} / 2,34^{* *}\end{array}$ \\
\hline MP2 & $\begin{array}{l}\mathrm{P}_{\mathrm{st}} \leq 0,8 \\
\mathrm{P}_{\mathrm{lt}} \leq 0,6\end{array}$ & $\begin{array}{l}\mathrm{L} 1-1,57 * \\
\mathrm{~L} 2-1,59 * \\
\mathrm{~L} 3-1,63^{*}\end{array}$ & $\begin{array}{l}\mathrm{L} 1-1,53^{*} \\
\mathrm{~L} 2-1,55^{*} \\
\mathrm{~L} 3-1,53^{*}\end{array}$ \\
\hline MP3 & $\begin{array}{l}\mathrm{P}_{\mathrm{st}} \leq 0,8 \\
\mathrm{P}_{\mathrm{lt}} \leq 0,6\end{array}$ & $\begin{array}{l}\mathrm{L} 1-1,50 * \\
\mathrm{~L} 2-1,55^{*} \\
\mathrm{~L} 3-1,58 *\end{array}$ & $\begin{array}{l}\mathrm{L} 1-1,45^{*} \\
\mathrm{~L} 2-1,54^{*} \\
\mathrm{~L} 3-1,48^{*}\end{array}$ \\
\hline MP4 & $\begin{array}{c}\text { Pst-/ } \\
\mathrm{P}_{\mathrm{lt}} \leq 1,0\end{array}$ & $\begin{array}{l}\mathrm{L} 1-1,32 * \\
\mathrm{~L} 2-1,35 * \\
\mathrm{~L} 3-1,38 *\end{array}$ & $\begin{array}{l}\text { L1 }-1,28^{*} \\
\text { L2 }-1,28^{*} \\
\text { L3 }-1,29 *\end{array}$ \\
\hline MP5 & $\begin{array}{c}\text { Pst-/ } \\
\mathrm{P}_{\mathrm{lt}} \leq 1,0\end{array}$ & $\begin{array}{l}\mathrm{L} 1-1,27 * \\
\mathrm{~L} 2-1,29 * \\
\mathrm{~L} 3-1,28 *\end{array}$ & $\begin{array}{l}\mathrm{L} 1-1,21^{*} \\
\mathrm{~L} 2-1,24^{*} \\
\mathrm{~L} 3-1,18^{*}\end{array}$ \\
\hline MP6 & $\begin{array}{c}\text { Pst-/ } \\
\mathrm{P}_{\mathrm{lt}} \leq 1,0\end{array}$ & $\begin{array}{l}\text { L1 }-1,30^{*} \\
\text { L2 }-1,31^{*} \\
\text { L3 }-1,26^{*}\end{array}$ & $\begin{array}{l}\mathrm{L} 1-1,19^{*} \\
\mathrm{~L} 2-1,24 * \\
\mathrm{~L} 3-1,15^{*}\end{array}$ \\
\hline$* *_{-}$ & $\begin{array}{l}\text { These values re } \\
\text { monitoring time } \\
61000-3-7: 2008 \\
\text { These values re } \\
\text { monitoring time, } \\
\text { Croatian Power }\end{array}$ & $\begin{array}{l}\text { er to the maximum } \\
\text { according to the } \\
\text { nd International stand } \\
\text { or to the maximum } \\
\text { which is consistent } \\
\text { ystem. }\end{array}$ & $\begin{array}{l}\text { value in } 95 \% \text { of the } \\
\text { echnical report IEC } \\
\text { ard EN } 50160: 2008 \\
\text { alue in } 100 \% \text { of the } \\
\text { ith the Grid Code of }\end{array}$ \\
\hline
\end{tabular}

Table III. Shows that in all measuring points flicker severity exceeds prescribed limits according to the Grid Code of Croatian Power System (NN 36/06), permissible limits according to the planning levels given in Technical 
Report IEC 61000-3-7:2008 and permissible limits according to International Standard EN 50160:2008.

\section{Calculation of Transfer Coefficients}

Taking into account that measurement results of flicker severity are very high (for all measurement points) and exceed recommended planning level according to International Technical Report IEC 61000-3-7:2008 (MP1, MP2 and MP3), permissible limits according to International norm EN 50160:2008 (MP4, MP5 and MP6) and prescribed limits according to Grid Code of Croatian Power System for MP1, comparison of flicker severity for different measurement points was made. Purpose of this comparison is to determine attenuation of flicker severity in power system.

Comparison of measurement results of flicker severity at different measuring points is shown on Figure 3 (values in $100 \%$ of the monitoring time) and Figure 4 (values in $95 \%$ of the monitoring time). Short-term and long-term flicker severity values for every phase and every measurement point are given. Measurement points are sorted by "electrical" and space distance from the flicker severity source (new electric arc furnace in 110/35(33) kV "Željezara 1" substation). 220/110 kV "TE Sisak" substation is located left from the source of flicker, and all other measurement points are located on the right side (opposite sides than on the Figure 2.). From the electrical point of view 220/110 kV "TE Sisak" substation is electrically closer to the flicker source than $110 / 35 \mathrm{kV}$ substation "Pračno", because of the length of the $110 \mathrm{kV}$ overhead line. Also, measurement results of flicker severity are higher in 220/110 kV "TE Sisak" substation, then in 110/35 kV "Pračno" substation.

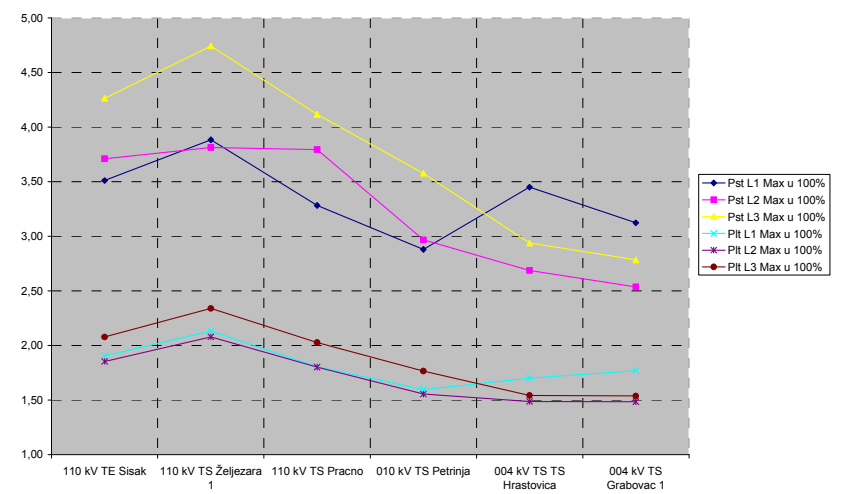

Fig. 3. Comparison of short-term and long-term flicker severity values in all six measurement points, $\mathrm{P}_{\mathrm{st}} \mathrm{i} \mathrm{P}_{\mathrm{lt}}$ in

$100 \%$ of the monitoring time for all three phases

High values of flicker severity during the measurement period were expected, because of the relatively big rated power (63 MVA) of new arc furnace of the existing network customer. Slight attenuation of flicker severity as the measuring point moves away from the flicker source (as a function of the length of the network itself, and through the transformations on the lower voltage levels) can be seen at the Figure 3 and Figure 4. That is especially visible on the short-term and long-term flicker severity values in $95 \%$ of the monitoring time (Figure 4 ), when the highest values in $5 \%$ of the monitoring time are eliminated (those values can vary due to events in the power systems like voltage dips or similar).

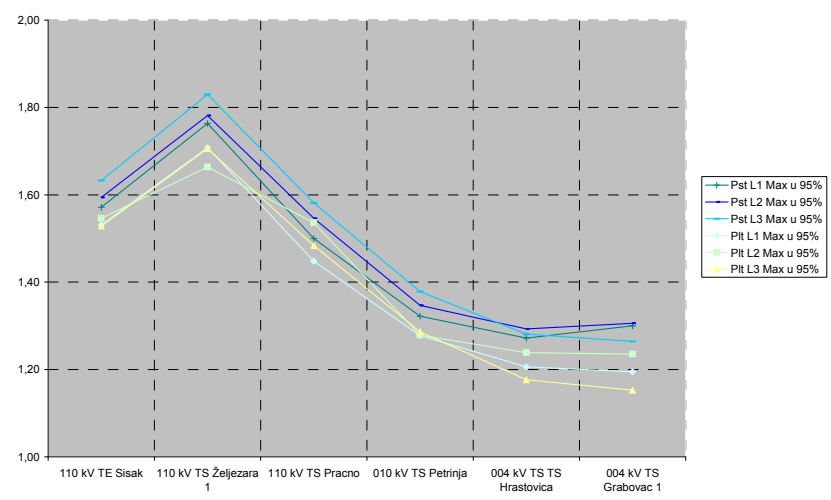

Fig. 4. Comparison of short-term and long-term flicker severity values in all six measurement points, $\mathrm{P}_{\mathrm{st}} \mathrm{i} \mathrm{P}_{\mathrm{lt}}$ in $95 \%$ of the monitoring time for all three phases

From the measurement results given above, flicker transfer coefficients between different voltage levels can be obtained. Taking into account that dominant flicker sources are located in industrial network and connected to the $110 / 35(33) \mathrm{kV}$ "Željezara 1" substation, flicker transfer coefficients can be calculated as $\mathrm{T}_{\mathrm{Pst}} \mathrm{AB}=\mathrm{P}_{\mathrm{st}}(\mathrm{B}) / \mathrm{P}_{\mathrm{st}}(\mathrm{A})$. Flicker transfer coefficient is relevant for attenuation of flicker severity values through the power grid. Flicker transfer coefficients $\mathrm{T}_{\mathrm{Pst}} \mathrm{AB}$ for short-term flicker severity between different voltage levels are calculated and given in table IV. Short-term and flicker severity values in $95 \%$ of the monitoring time are taken in to account for flicker transfer coefficient calculation. During calculation these are the substations that are taken into account: for $110 \mathrm{kV}$ voltage level 110/35 kV substation "Pračno", for $10 \mathrm{kV}$ voltage level $110 / 10 \mathrm{kV}$ substation "Petrinja" and for $0,4 \mathrm{kV}$ voltage level 10/0,4 kV substation "Hrastovica" and 10/0,4 kV substation "Banski Grabovac 1".

Results given in table 4 show that attenuation of flicker is maximum $20 \%$, between $110 \mathrm{kV}$ voltage level $110 / 35 \mathrm{kV}$ substation "Pračno" and 10/0,4 kV substation "Banski Grabovac1". Attenuation of flicker between $110 \mathrm{kV}$ and $10 \mathrm{kV}$ voltage level is maximum $13 \%$, and between 10 $\mathrm{kV}$ and $0,4 \mathrm{kV}$ voltage level maximum $8 \%$. 
Table IV. - Flicker transfer coefficients $\mathrm{T}_{\mathrm{Pst}} \mathrm{AB}$ for short-term flicker severity between different voltage levels [2]

\begin{tabular}{|c|c|c|}
\hline $\begin{array}{c}\text { FLICKER TRANSFER } \\
\text { COEFFICIENT } \\
\text { T }_{\text {PstAB }} \\
\text { BETWEEN DIFFERENT } \\
\text { VOLTAGE LEVELS } \\
\end{array}$ & $\begin{array}{c}\text { VALUE } \\
\text { OF } \\
\text { T }_{\text {Pst }} \mathbf{A B}\end{array}$ & $\begin{array}{l}\text { VOLTAGE } \\
\text { LEVELS }\end{array}$ \\
\hline $\mathrm{T}_{\mathrm{Pst95 \%}}$ Pračno-Petrinja & $\begin{array}{l}\text { L1 }-0,88 \\
\text { L2 }-0,87 \\
\text { L3 }-0,87\end{array}$ & $110 \mathrm{kV}-10 \mathrm{kV}$ \\
\hline $\mathrm{T}_{\mathrm{Pst} 95 \%}$ Petrinja-Hrastovica & $\begin{array}{l}\text { L1 }-0,96 \\
\text { L2 }-0,96 \\
\text { L3 }-0,93\end{array}$ & $\begin{array}{c}10 \mathrm{kV}-0,4 \mathrm{kV} \\
\text { (first substation) }\end{array}$ \\
\hline $\mathrm{T}_{\mathrm{Pst}_{55 \%} \text { Petrinja-Banski Grabovac } 1}$ & $\begin{array}{l}\text { L1 }-0,98 \\
\text { L2 }-0,97 \\
\text { L3 }-0,92\end{array}$ & $\begin{array}{c}10 \mathrm{kV}-0,4 \mathrm{kV} \\
\text { (last substation) }\end{array}$ \\
\hline $\mathrm{T}_{\mathrm{Pst} 95 \%}$ Pračno-Hrastovica & $\begin{array}{l}\text { L1 }-0,85 \\
\text { L2 }-0,84 \\
\text { L3 }-0,81\end{array}$ & $\begin{array}{l}110 \mathrm{kV}-0,4 \mathrm{kV} \\
\text { (first substation) }\end{array}$ \\
\hline $\mathrm{T}_{\mathrm{Ps}_{\mathrm{s} t 5 \%} \%}$ Pračno -Banski Grabovac 1 & $\begin{array}{l}\text { L1 }-0,87 \\
\text { L2 }-0,84 \\
\text { L3 }-0,80\end{array}$ & $\begin{array}{l}110 \mathrm{kV}-0,4 \mathrm{kV} \\
\text { (last substation) }\end{array}$ \\
\hline $\mathrm{T}_{\mathrm{Pst95 \%} / \text { Pračno-Petrinja }}$ & $\begin{array}{l}\text { L1 }-0,88 \\
\text { L2 }-0,87 \\
\text { L3 }-0,87\end{array}$ & $110 \mathrm{kV}-10 \mathrm{kV}$ \\
\hline
\end{tabular}

\section{Conclusion}

Voltage Quality at some point of the power system is responsibility of both system operator and network customers connected to that point. To maintain a certain level of Voltage Quality (necessary for proper operation of equipment that is connected to the power system) at some point in the network is mission of system operator. This mission is performed by limiting negative influence of all network customers and their equipment, by the system operator. Every network customer is obliged to keep his negative influence on Power Quality (harmonics, reactive power, flicker emission, load unbalance) below prescribed limits (which are determined by the system operator).

On the basis of Power Quality measurement results on the point of connection of Ironworks "Sisak" and Voltage Quality measurement results in surrounding transmission and distribution power grid it can be concluded that operation of new electric arc furnace causes very high flicker emission on the point of connection $(110 \mathrm{kV}$ voltage level in 110/35(33) kV "Željezara 1" substation). This conductive disturbance propagates through transmission power system and in $50 \mathrm{~km}$ circle exceeds prescribed limit for flicker severity according to Grid Code of Croatian Power System. Flicker severity values attenuate as the measurement point moves away from the flicker source (new electric arc furnace) by distance and voltage levels. Flicker transfer coefficients that are calculated can give a clearer picture of the attenuation of flicker through the power network. Attenuation of flicker is maximum $20 \%$ between $110 \mathrm{kV}$ voltage level $110 / 35$ kV substation "Pračno" and 10/0,4 kV substation "Banski Grabovac1". Attenuation of flicker between $110 \mathrm{kV}$ and $10 \mathrm{kV}$ voltage level is maximum $13 \%$, and between 10 $\mathrm{kV}$ and $0,4 \mathrm{kV}$ voltage level maximum $8 \%$.

From these results it can be concluded that the propagation of flicker through the system has very small attenuation. Because of that flicker problem is effectively and better to reduce or solve on the point of connection of flicker source, for example by installing dynamic or static compensation device, depending on the specific problem. Flicker values that exceed permissible values can be reduced in several ways: increasing the shortcircuit power at the point of connection of flicker source network user, Installing SVC compensation (reduction factor of flicker between 1,5 and 2) or installing STATCOM compensation (reduction factor of flicker between 3 and 6). Considering methods of flicker reduction, in cases similar to one described in this paper (reducing flicker values that exceed double permissible limits), it is more economically justifiable to invest in equipment for compensation (SVC, STATCOM) than to invest in the construction of power system to increase short-circuit power.

\section{References}

[1] Grid Code of Croatian Power System (Official Gazette 36/06) .

[2] IEC/TR 61000-3-7: 2008, Electromagnetic compatibility (EMC) - Part 3-7: Limits - Assessment of emission limits for the connection of fluctuating installations to MV, HV and EHV power systems"

[3] IEC/TR 61000-3-6: 2008, Electromagnetic compatibility (EMC) - Part 3-6: Limits - Assessment of emission limits for the connection of distorting installations to MV, HV and EHV power systems"

[4] IEC/TR 61000-3-13: 2008, Electromagnetic compatibility (EMC) - Part 3-13: Limits Assessment of emission limits for the connection of unbalanced installations to MV, HV and EHV power systems"

[5] EN 50160:2008 "Voltage characteristics of electricity supplied by public distribution networks"

[6] Tomasović, Ana; Lasić, Mate; Barukčić, Dražen; Šimić, Jandro, "Determination of negative influence on voltage quality in CMC Sisak and other substations in transmission power system surrounding CMC Sisak after first phase of installing the new electric arc furnace", 10. savjetovanje HRO CIGRÉ, Cavtat, November 2011. 